\title{
Konsep Pendidikan Informal Perspektif Ibnu Sahnun (Telaah Kitab Adab Al-Muallimin)
}

\author{
Anisatun Nur Laili ${ }^{1}$ \\ ${ }^{1}$ INSUD Lamongan \\ 1anisatun.nurlaili@yahoo.co.id
}

\begin{abstract}
The family is the holder of control in informal education, especially in shaping the religious character of children from an early age. The intellectual, social, and emotional development of children is very fast in the golden age so that parents as holders of an important role in children's development must have the readiness and knowledge that is qualified for the successful implementation of informal education. This research is a library research that focuses on examining the thoughts of Ibn Sahnun, a scholar in the field of education in the 2 nd century $\mathrm{H}$. Related to the concept of informal education which he wrote in the book of Adab al-Mu'allimin. According to Ibnu Sahnun the main curriculum in informal education is the education of the Qur'an so that it is integrated with the general knowledge acquired by children in formal education. The obligation to educate is absolutely the property of parents, in addition to preparing knowledge, parents must also form noble qualities in themselves as educators, including patience, sincerity, fairness, responsibility, and gentle in educating. However, if parents really are not able to educate their children, then they are obliged to find a teacher for their children and give a salary to the teacher, but still supervise and accompany their children
\end{abstract}

Keywords: Adab Al-Muallimin, Ibn Sahnun, Informal Education.

\begin{abstract}
Abstrak
Keluarga adalah pemegang kendali dalam pendidikan informal, terutama dalam pembentukan karakter religius anak sejak usia dini. Perkembangan intelektual, sosial, dan emosional anak sangat cepat di masa golden age sehingga orang tua sebagai pemegang peranan penting dalam perkembangan anak harus memiliki kesiapan dan pengetahuan yang mumpuni demi kesuksesan penyelenggaraan pendidikan informal. Penelitian ini merupakan penelitian kepustakaan yang fokus menelaah pemikiran Ibnu Sahnun, seorang ulama dalam bidang pendidikan abad ke-2 $\mathrm{H}$. Terkait konsep pendidikan informal yang telah ia tulis dalam kitab Adab al-Mu'allimin. Menurut Ibnu Sahnun kurikulum utama dalam pendidikan informal adalah pendidikan AlQur'an agar terintegrasi dengan ilmu pengetahuan umum yang didapatkan anak dalam pendidikan formal. Kewajiban mendidik adalah mutlak milik orang tua, selain menyiapkan pengetahuan orang tua juga harus membentuk sifat-sifat yang luhur dalam dirinya sebagai pendidik, di antaranya sabar, ikhlas, adil, bertanggungjawab, dan lemah lembut dalam mendidik. Namun, jika orang tua benar-benar tidak mampu mendidik anak-anaknya, maka
\end{abstract}


mereka berkewajiban mencari guru untuk anaknya dan memberi upah pada guru, namun tetap mengawasi serta mendampingi anak-anaknya.

Kata Kunci: Adab al-Muallimin, Ibnu Sahnun, Pendidikan Informal.

\section{Pendahuluan}

Pendidikan merupakan sebuah proses berkepanjangan dan berkelanjutan sampai akhir hayat manusia, maka tidak heran apabila permasalahan dalam pendidikan selalu menjadi sesuatu yang aktual dan dituntut untuk selalu relevan dengan kontinuitas dinamika kehidupan. Menurut Oemar Hamalik, manusia yang berkualitas dapat dilihat dari segi pendidikannya, maka proses pendidikan tidak dapat terlepas dari tujuan pembangunan nasional. ${ }^{1}$

Dalam UU Sisdiknas Nomor 20 Tahun 2003 disebutkan bahwa pendidikan dapat dilakukan melalui tiga jalur yang sering dikenal sebagai tri sentra pendidikan, yakni pendidikan formal, pendidikan non formal, dan pendidikan informal, ketiganya dapat saling melengkapi dan memperkaya. ${ }^{2}$ Pendidikan merupakan tanggung jawab bersama dan membutuhkan kerjasama antara pemerintah, masyarakat, dan keluarga. Apabila ketiga aspek tersebut bersinergi secara maksimal maka tidak akan sulit untuk meningkatkan kualitas bangsa dari segi pendidikan.

Lebih lanjut dalam pasal 27 ditegaskan bahwa pendidikan informal dapat dilakukan oleh keluarga dan lingkungan dalam bentuk kegiatan belajar secara mandiri dan hasil pendidikan tersebut diakui seperti pendidikan formal dan nonformal setelah peserta didik lulus ujian sesuai dengan standar nasional pendidikan. Kemudian dalam pasal 28 dan 29 masih dalam undang-undang yang sama disebutkan pendidikan yang dapat ditempuh dalam pendidikan informal adalah pendidikan anak usia dini dan pendidikan keagamaan. Hal tersebut menunjukkan bahwa pemerintah mengakui peranan penting pendidikan informal terutama untuk membentuk karakter religius anak sejak usia dini.

Di antara peranan penting keluarga untuk membentuk karakter anak adalah membentuk sikap, pendidikan agama, keterampilan dasar, budi pekerti, kasih sayang, sopan santun, tanggung jawab, serta menanamkan kebiasan-kebiasaan baik dan normanorma yang berlaku dalam masyarakat. Keluarga adalah satuan terkecil dalam masyarakat, jika keluarga dibina dengan baik maka masyarakat akan menjadi baik.

\footnotetext{
${ }^{1}$ Oemar Hamalik, Kurikulum dan pembelajaran (Jakarta: Bumi Aksara, 2017), 1.

2 “Undang-Undang Nomo2 30 tahun 2003 tentang Sistem Pendidikan Nasional," 2003, Pasal 13.
} 
Muhajir Efendi mengatakan bahwa pendidikan harus dimulai dari keluarga dan orang tua sebagai pendidik utama. Akan tetapi realita yang terjadi justru sebaliknya, penyerahan tanggung jawab justru mutlak diberikan kepada pihak sekolah dengan alasan orang tua sibuk bekerja, orang tua tidak mampu mendidik, atau karena persoalan ekonomi dan hilangnya keharmonisan keluarga. Padahal jika orang tua mampu menyelaraskan visi misi dengan sekolah dan mau mendampingi anak dalam proses pendidikan, hal tersebut akan sangat membantu untuk melejitkan potensi anak dalam berbagai bidang, baik itu dari segi akademik, emosional dan juga spiritual. ${ }^{3}$

Selain keluarga yang tidak mau ikut andil dalam proses pendidikan anaknya, permasalahan bagi keluarga yang mau mendampingi proses pendidikan juga cukup beragam, salah satunya adalah kurangnya edukasi terkait pendidikan informal bagi mereka baik secara teori maupun praktik, sehingga yang terjadi justru orang tua memaksa anaknya untuk belajar tanpa memahami fitrah anak. Akibatnya juga fatal, anak bukannya malah semangat dalam belajar, tetapi justru memiliki rasa trauma sendiri akibat pola pendidikan yang diberikan oleh orang tuanya.

Berbagai permasalahan tersebut membuat penulis tertarik untuk membuat tulisan yang berhubungan dengan konsep pendidikan informal dengan cara mengkaji kembali pemikiran ulama klasik yaitu Ibnu Sahnun. Beliau dikenal sebagai ulama dalam pendidikan dasar Islam yang sangat perhatian terhadap masalah-masalah yang ada di pendidikan Islam, terbukti dari salah satu buku beliau dengan judul Adab al-Muallimin yang membahas tentang kurikulum pendidikan, tujuan, metode, hingga manajemen pendidikan. Buku tersebut juga digunakan sebagai acuan pendidikan dan pengajaran anak-anak di Kuttab pada masanya, dan juga dipakai rujukan oleh ulama di bidang pendidikan setelahnya, seperti Al-Qabisi. Penulis berharap hasil penelitian ini dapat dijadikan sebagai bacaan untuk menambah khazanah keilmuan sekaligus menjadi salah satu rujukan bagi praktisi pendidikan, khususnya sebagai rujukan secara konseptual dan praktik untuk pejuang pendidikan informal.

\section{Metode Penelitian}

Penelitian ini adalah penelitian kepustakaan (library research) yakni penelitian yang cara mendapatkan informasi datanya bersumber dari literatur atau buku-buku. ${ }^{4}$

\footnotetext{
${ }^{3}$ Munif Chatib, Orangtuanya Manusia: Melejitkan Potensi dan Kecerdasan dengan Menghargai Fitrah Setiap Anak (Bandung: Kaifa, 2013), 18.

${ }^{4}$ Mardalis, Metode penelitian: suatu pendekatan proposal (Jakarta: Bumi Aksara, 2014), 28. 
Penelitian ini digunakan untuk memecahkan problem yang bersifat konseptual teoretis dengan cara meneliti pemikiran Ibnu Sahnun terkait konsep pendidikan informal.

Metode pengumpulan data dalam penelitian ini yaitu dengan cara menelaah dan mengkaji sumber primer dan beberapa sumber sekunder sebagai bahan analisis untuk penelitian. ${ }^{5}$ Sumber primer yang dimaksud di sini adalah kitab Adab al-Muallimin karya Ibnu Sahnun, dan sumber sekunder adalah penelitian terkini yang relevan dengan konsep pendidikan Informal. Sedangkan metode analisis data untuk penelitian ini menggunakan deskriptif analisis, ${ }^{6}$ yaitu pengambilan kesimpulan terhadap sebuah konsep atau pemikiran serta hubungannya dengan fenomena yang dianalisis.

\section{Pembahasan}

\section{Biografi Ibnu Sahnun}

Ibnu Sahnun bernama lengkap Abdullah Muhammad bin Abu Sa'id Sahnun bin Sa'id bin Habib bin Hilal bin Bakar bin Rabi'ah At-Tanukhi. Ayahnya dikenal dengan nama julukannya, yaitu Sahnun yang berarti burung yang memiliki pandangan tajam. ${ }^{7}$ Ibnu Sahnun (Anaknya Sahnun) seorang ulama fikih dan pendidikan yang lahir pada tahun 202 H (awal abad ke-3 H/ abad ke-9 M) di Gadat, Qairawan. Adapun tanggal dan bulan kelahirannya tidak diketahui secara pasti karena tidak ditemukan dalam buku karangannya atau buku penulis yang menulis tentangnya, namun yang pasti ia hidup di masa Daulah Bani Abbasiyah.

Pendidikan pertama Ibnu Sahnun didapatkan dari ayahnya, Abu Sa'id Sahnun, seorang ilmuwan pada masa itu. Maka tidak mengherankan apabila dikatakan bahwa ayahnya sangat berpengaruh besar terhadap pembentukan kepribadian dan pemikiran Ibnu Sahnun. Abu Sa'id dapat melihat tanda-tanda kecerdasan anaknya, dalam usia muda Ibnu Sahnun sudah mampu menguasai kitab-kitab tulisan ayahnya, sehingga ia dimasukkan ke Kuttab di Qairawan untuk belajar Al-Qur'an dan dasar-dasar agama.

Pada usia remaja, Ibnu Sahnun melakukan perjalanan intelektual ke Maghrib (Maroko, Tunis), Mesir, dan Masyriq (Makkah, Madinah) untuk menghafal Al-Qur'an dan belajar ilmu-ilmu yang berhubungan dengan Al-Qur'an dan gramatika. Dilanjutkan dengan ilmu syariat, bahasa, sejarah, dan sebagainya kepada para ulama, di antaranya

\footnotetext{
${ }^{5}$ Suharsimi Arikunto, Prosedur penelitian: suatu pendekatan praktik (Jakarta: Rineka Cipta, 2011), 131.

${ }^{6}$ Moh Nazir, Metode penelitian (Jakarta: Ghalia Indonesia, 2011), 63.

7 Abdurrahman Mas'ud, Pemikiran Emas Para Tokoh Pendidikan Islam (Yogyakarta: Arruz Media, 2017), 133.
} 
adalah Abdul Aziz bin Yahya Al-Madani, Musa bin Mu'awiyah As-Samadihi, Abdur Rahman bin Al-Qasim,Abdullah bin Abi Hisan Al-Yahsabi, dan Ibnu Abd al-Hakam. ${ }^{8}$

Karya-karya Ibnu Sahnun dalam berbagai bidang ilmu sekitar 200 buku, ${ }^{9}$ di antaranya adalah 20 (1) Al-Jami', kitab ini terdiri dari 100 juz atau lebih dan merupakan sebuah karya terbesar Ibnu Sahnun yang di dalamnya mengandung berbagai disiplin ilmu, di antaranya; 20 juz tentang biografi, 50 juz tentang ilmu faraidh, 25 juz tentang amtsal (perumpamaan), 8 juz tentang sejarah para tokoh,10 juz tentang tata cara dalam mengambil keputusan, dan lain sebagainya. Kitab tersebut adalah sebuah ensiklopedi ilmu pengetahuan lengkap yang ada pada masa itu; (2) Al-Imamah (3) Tahrimul Muskir (4) Al-Musnad, yang merupakan kitab tebal berisi hadith-hadith (5) Tafsir Al-Muwatha' Imam Malik, yang terdiri dari 4 Juz (6) Masailul Jihad, terdiri dari 20 juz (7) Ar-Raddu 'alaa Ahlil Bid'i, terdiri dari 3 juz (8) Thabaqatul Ulama', terdiri dari 7 juz (9) AtTarikh (10) Al-Iman war Radd 'alaa Ahli Syirki (10) Asyribah wa Gharibul Hadis, terdiri dari 3 juz (12) Hujjah alal Qadariyah (13) Hujjah alan Nashara (14) Raddul Fikriyyah. Masih banyak lagi kitab yang ditulis oleh Ibnu Sahnun, namun semua kitab tersebut tidak ditemukan keberadaannya saat ini. Adapun kitab yang ada hingga saat ini dan sampai pada kita adalah Adabul Muallimin atau Al-Muallimin wal Mutallimin.

Karya-karya Ibnu Sahnun tersebut mencakup berbagai disiplin ilmu pengetahuan, baik itu hadith, tafsir, politik, akhlak, sejarah, dan juga pendidikan, sehingga Ibnu Sahnun dikenal sebagai seorang mufassir, muhaddith, teolog, sejarawan, agamawan, dan pedagogik Islam. Selain itu, Ibnu Sahnun juga seorang politikus, terbukti dengan diangkatnya beliau sebagai Qadhi di Afrika Utara hingga ia meninggal pada tahun 256 $\mathrm{H}$ atau bertepatan dengan usia 54 Tahun. ${ }^{10}$

\section{Kitab Adab al-Muallimin}

Kitab Adab al-Muallimin adalah salah satu karya masterpiece Ibnu Sahnun dalam bidang pendidikan Islam. Kitab tersebut pertama kali diterbitkan di Tunisia pada tahun $1350 \mathrm{H}$, walau kitab tersebut hanya berisi 28 halaman, tetapi di dalamnya memuat halhal signifikan terkait dasar-dasar pendidikan anak, metodologi, serta aturan dalam mendidik anak, dan juga dilengkapi dengan berbagai referensi dari Al-Qur'an dan

\footnotetext{
${ }^{8}$ Muhammad bin Sahnun, Kitab Adab al-Muallimin, pentahqiq Hasan Husni Abdul Wahhab, cet baru; murajaah dan komentar oleh Muhammad Arusi Al-Mathwi (Tunis: Dar Bussalamah Li Thab'ah wan Nasyr, t.t.), 15.

${ }^{9}$ Sahrizal dan Rabi'atul Adawiah, Pemikiran Pendidikan Islam Ibnu Sahnun (Miqot, 2012), 142.

${ }^{10}$ Yanuar Arifin, Pemikiran-Pemikiran Emas Para Tokoh Pendidikan Islam (IRCiSoD, 2018), 41.
} 
Hadith terkait konsep seorang pendidik. Maka tidaklah heran jika kitab Adab alMuallimin dijadikan sebagai acuan untuk pengajaran dan pendidikan anak di Kuttab pada masa itu.

Karya ini berisi 10 pasal pendek yang sebagian merupakan dialog Ibnu Sahnun dengan ayahnya, dan juga kutipan-kutipan riwayat hasil diskusi dengan orang lain dengan disertai beberapa komentar singkat. Adapun pokok-pokok 10 pasal yang ada dalam kitab tersebut adalah sebagai berikut: pembelajaran Al-Qur'an, kewajiban berlaku adil terhadap anak didik, dzikir yang makruh untuk dihapus, adab dalam memberikan hukuman (punishment), menuntaskan materi pelajaran, penetapan hadiah untuk pendidik, pemberian libur pada anak didik, kode etik pendidik dan peserta didik, memberi gaji kepada pendidik, aturan meminjamkan buku atau literature.

\section{Urgensi Pendidikan Informal}

Pendidikan informal yang dalam hal ini adalah keluargamerupakan lembaga pendidikan tertua dan utama dalam perkembangan potensi anak. ${ }^{11}$ Sebagai lembaga pendidikan informal, pendidikan dalam keluarga memiliki kegiatan belajar yang dilakukan secara mandiri dan tidak baku, sehingga tidak ada ketentuan yang kaku terkait struktur dan waktu pembelajaran. Keluarga menjadi lembaga pendidikan tertua karena masa pendidikan anak dimulai sejak dalam kandungan, dan menjadi lembaga pendidikan utama karena keberhasilan pendidikan keluarga untuk anak usia dini sangat menentukan keberhasilan anak dalam usia selanjutnya.

Belakangan ini pendidikan anak usia dini mendapatkan perhatian penuh oleh pemerintah. Proses pertumbuhan dan perkembangan anak pada 1000 hari pertama kehidupan merupakan sebuah proses yang sangat penting bagi setiap individu, karena pada masa ini pertumbuhan fisik, perkembangan intelektual, keterampilan motorik, sosial, dan emosi berjalan sangat cepat, sehingga para ahli mengatakan bahwa keberhasilan perkembangan pada tahun-tahun pertama akan menentukan keberhasilan masa depan seorang anak. ${ }^{12}$

Keluarga menjadi salah satu faktor penentu bagi keberhasilan perkembangan anak baik secara fisik maupun mental, terutama peran seorang ibu, hal tersebut dikarenakan ibu merupakan ikon madrasatul ula atau pendidik pertama bagi anak- anaknya. Setiap ragam pola asuh yang diterapkan oleh seorang ibu dalam membentuk pengetahuan,

\footnotetext{
11 "Undang-Undang Nomo2 30 tahun 2003 tentang Sistem Pendidikan Nasional," pasal 27.

${ }^{12}$ Meta Hanindita, Mommyclopedia (Jakarta: Gramedia, 2019), 50.
} 
keterampilan, dan tingkah laku seorang anak sangat penting karena masing-masing akan memberikan dampak yang berbeda. Oleh sebab itu, pendidikan informal sangat berperan dalam mengembangkan kepribadian, moral, watak, nilai-nilai budaya, keagamaan, serta keterampilan sederhana yang tidak didapatkan dari pendidikan formal maupun non formal.

Masa pendidikan formal di sekolah berkisar antara tujuh hingga sembilan jam, jika ditambah pendidikan nonformal seperti kursus selama satu jam maka genap menjadi sepuluh jam, dan empat belas sisanya anak akan kembali menjalani pendidikan informal. Apabila pengetahuan dan keterampilan yang didapat di sekolah atau lembaga kursus tidak diperkuat dengan pendidikan dalam keluarga, tentu akan sulit sekali mengoptimalkan potensi anak. Terlebih dalam pendidikan moral atau akhlak, pemerintah dan masyarakat harus bekerja sama dengan keluarga untuk mewujudkannya sesuai dengan amanat undang-undang Sisdiknas untuk saling melengkapi dan memperkaya antara pendidikan formal, nonformal, dan informal. ${ }^{13}$

Salah satu peran pendidikan informal dalam pembentukan karakter dan kepribadian anak adalah menstimulus kecerdasan lingusitik anak dengan cara mengajarkan pada anak bagaimana tata cara berbahasa dalam pergaulan sehari-hari. Orang tua juga bisa merangsang kecerdasan intrapersonal anak dengan pembiasan perilaku yang sesuai dengan lingkungan budaya setempat, seperti membiasakan anak untuk menghargai hasil karya sendiri bagaimanapun bentuknya dan orang tua menyontohkan perilaku teladan dengan tidak membandingkan hasil karya anak dengan hasil karya saudara atau teman-temannya.

Peran orang tua dalam pendidikan informal tidak terbatas waktu ataupun materi. Saat anak sudah beranjak remaja atau dewasa, orang tua tetap memiliki peranan yang sangat penting karena pendidikan informal tidak hanya mengajarkan anak tentang berbicara, bernyanyi, menari, atau kepentingannya sendiri, tetapi juga mengajarkan keterampilan yang berhubungan dengan kehidupan sosial. Terlebih terkait nilai-nilai moral dan akhlak terpuji sehingga peranan orang tua selalu dibutuhkan dalam pendidikan informal sampai kapanpun. ${ }^{14}$

Suksesi pendidikan informal tidak terlepas dari kepribadian orang tua. Selain membekali diri dengan pengetahuan yang cukup dalam membimbing anak, orang tua

\footnotetext{
13 "Undang-Undang Nomo2 30 tahun 2003 tentang Sistem Pendidikan Nasional," pasal 13.

14 That Hatimah, "REGULASI DAN IMPLEMENTASI PENDIDIKAN INFORMAL," PEDAGOGIA 13, no. 1 (2015): 194-202, https://doi.org/10.17509/pedagogia.v13i1.3387.
} 
juga perlu membentuk dirinya agar berkepribadian baik guna menjadi pendidik di lembaga informal. Hal tersebut dikarenakan anak tidak hanya menyerap knowledge tapi juga menyerap value yang diteladankan orang tua. Anak mengerti konsep baik buruk atau benar salah dimulai dari keluarga, setiap tata nilai yang ada dalam keluarga akan membentuk karakter seorang anak.

\section{Konsep Pendidikan Informal Ibnu Sahnun}

Amanat UU Sisdiknas pasal 13 dapat dipahami dengan jelas bahwa pendidikan formal, pendidikan non formal, dan pendidikan informal harus saling melengkapi dan memperkaya guna menciptakan manusia unggul dan berkualitas. Namun tidak dapat dipungkiri praktik yang terjadi di masyarakat kita adalah pendidikan formal berada di strata tertinggi dan pendidikan informal cenderung diabaikan. Salah satu sebabnya adalah tidak ada struktur yang baku dalam pendidikan informal, padahal untuk menciptakan generasi yang berkualitas, harus ada kerjasama yang solid antara ketiganya, yakni antara sekolah, keluarga, dan masyarakat.

Pada zaman klasik pendidikan formal hanya didapatkan di Kuttab, sehingga pendidikan informal punya peranan yang sangat signifikan bagi seorang anak. Ibnu Sahnun adalah salah satu produk pendidikan informal yang berhasil, ayahnya sebagai pendidik pertama berhasil membentuk pola pikir dan karakternya, meskipun saat dewasa ia belajar ke masyriq dan maghrib namun tetap saja pemikiran dan karakternya banyak dipengaruhi oleh ayahnya.

Pendidikan informal dilakukan secara mandiri dalam lingkungan keluarga, tidak ada patokan menggunakan metode tertentu atau media tertentu, orang tua bisa mendidik secara spontan atau menanamkan nilai melalui beberapa pembiasaan. Hal itulah yang dilakukan oleh ayah Ibnu Sahnun, sejak kecil ia dibekali dengan pendidikan Al-Qur'an dan kandungan akan luasnya ilmu pengetahuan di dalamnya sehingga Ibnu Sahnun tumbuh dewasa dengan pemikiran yang tajam.

Pemikiran Ibnu Sahnun terkait pendidikan tertuang dalam kitab Adab alMuallimin, kitab tersebut dijadikan sebagai acuan untuk pendidikan anak-anak di Kuttab. Dalam kitab tersebut, setidaknya ada beberapa hal yang tetap layak diterapkan untuk masa sekarang, diantaranya terkait kurikulum inti dalam pendidikan informal, peranan penting orang tua dalam pendidikan informal, serta arahan bagi orang tua yang tidak mampu melaksanakan pendidikan informal.

1. Mengajarkan Al-Qur'an pada anak 
Konsep pembelajaran Ibnu Sahnun terdiri dari dua hal. Pertama, yang mengikat atau harus diajarkan, dalam hal ini adalah Al-Qur'an. Kedua, yang diajarkan secara suka rela atau tidak mengikat, yaitu matematika, syair, gramatika, dan lain sebagainya. Sahnun dalam kitabnya menjelaskan bahwa anak-anak wajib mempelajari Al-Qur'an. ${ }^{15}$ Bahkan Al-Qur'an harus diajarkan pertama kali kepada seorang anak, karena menurutnya Al-Qur'an adalah sumber ilmu untuk menghapus kebodohan, memelihara agama Islam, dan meraih kebahagiaan di dunia dan akhirat.

Di antara permasalahan pendidikan Islam yang terus menjadi perbincangan adalah terkait akhlak peserta didik. Meski pendidikan agama Islam sudah diberikan di tingkat paling dasar dalam pendidikan formal, bahkan tidak sedikit peserta didik yang mendapat nilai unggul dalam tes pelajaran PAI, namun tetap saja nilai kognitif belum mampu mengimbangi afeksi peserta didik. Hemat penulis, salah satu sebabnya adalah kurangnya kesadaran orang tua untuk menjalin kerjasama dengan pihak sekolah dalam bidang pengajaran dan pendidikan.

Al-Qur'an adalah kitab suci sekaligus pedoman hidup umat Islam. Di dalamnya memuat tuntunan segala aspek kehidupan, maka Al-Qur'an seharusnya diajarkan sebagai materi pertama dan utama dalam pendidikan dasar, dan yang bisa mengimplementasikannya adalah orang tua sebagai pendidik pertama seorang anak. Lebih lanjut Ibnu Sahnun mengatakan setelah belajar Al-Qur'an hendaknya anakanak diajarkan ilmu selain Al-Qur'an, baik itu bahasa, matematika, gramatika, dan lain sebagainya. Ini berarti Ibnu Sahnun tidak hanya menekankan Al-Qur'an sebagai satu-satunya materi pelajaran, ia bersifat pertama karena seyogyanya menjadi materi pertama bagi anak, dan menjadi utama agar lebih didahulukan daripada pelajaran lainnya, karena semua ilmu pengetahuan bersumber dari Al-Qur'an.

Menurut hasil riset Universitas Al-Azhar, membaca Al-Qur'an memiliki dampak meningkatkan kinerja otak serta mempertajam daya ingat hingga 80\%, terutama ketika waktu subuh karena pada saaat tersebut keadaan otak masih sangat fresh akibat recharge energi di malam hari. ${ }^{16}$ Saat seseorang membaca Al-Qur'an, setidaknya ada tiga aktivitas sekaligus yang ia kerjakan yaitu melihat, membaca, dan mendengar. Apabila ditambah lagi dengan penghayatan maka akan lebih berdampak pada kinerja otak dan sampai pada kalbu.

\footnotetext{
${ }^{15}$ Muhammad Ibn Sahnun, Adab al-Mu'allimin (Kairo: Darul Ma'arif, 1968), 351.

${ }^{16}$ Nur Hakim, "Kecerdasan Intelektual, Emosional, Dan Spiritual Dalam Perspektif Bidayatul Hidayah," Indonesian Journal of Islamic Education Studies (IJIES) 1, no. 2 (27 Desember 2018): 218-33, https://doi.org/10.33367/ijies.v li2.639.
} 
Oleh karena itu, dalam pendidikan informal orang tua tidak hanya dituntut untuk mengajarkan keterampilan dasar pada anak, seperti berbicara, berjalan, bernyanyi. Lebih dari itu, pendidikan informal adalah wahana yang paling krusial dalam pembentukan karakter anak sejak usia dini. Sebagai umat Islam yang berpedoman hidup pada Al-Qur'an sangat ditekankan untuk memberikan pendidikan qalbu melalui Al-Qur'an, selain membentuk akhlak mulia, di dalamnya juga terdapat banyak ilmu pengetahuan yang nantinya akan menjadi bekal positif bagi anak memulai pendidikan formal.

2. Kepribadian yang harus dimiliki pendidik

Beberapa kepribadian yang harus dimiliki oleh pendidik menurut Ibnu Sahnun adalah bertaqwa kepada Allah, adil, lemah lembut, berwibawa, ikhlas, sabar, tanggung jawab, dan perhatian terhadap anak didiknya. Selain membekali diri dengan ilmu pengetahuan yang mumpuni, orang tua sebagai pendidik utama dalam pendidikan informal juga harus membentuk dirinya agar memiliki kepribadian yang mulia.

Pertama, bertaqwa kepada Allah. Dalam tafsir Ibnu Katsir disebutkan bahwa taqwa adalah menaati Allah swt dan tidak bermaksiat kepadaNya. Menurut AlGhazali agar ilmu yang disampaikan oleh pendidik bisa sampai pada murid maka pendidik harus memiliki hati yang bersih. Sedangkan menurut Ibnu Sahnun, kepribadian seseorang itu tidak serta merta ada, melainkan harus dibentuk. Oleh karena itu, langkah pertama yang ditempuh oleh Abu Said Sahnun untuk mencerdaskan qalbu putranya adalah melalui pendidikan Al-Qur'an. ${ }^{17}$

Al-Qur'an adalah kitab suci yang berisi pedoman hidup. Ayat pertama yang turun adalah surat Al-Alaq 1-5, di dalamnya ada lafadl Iqra' yang berarti membaca. Kata membaca merupakan kata kerja sehingga ia tidak datang secara tiba-tiba, melainkan butuh sebuah usaha atau proses. Begitu juga dengan sifat taqwa, tidak mungkin tiba-tiba ada dalam diri manusia melainkan harus selalu diusahakan agar manusia memiliki akhlak yang baik dan mencapai derajat ketaqwaan. Oleh karena itu, orang tua sebagai pendidik utama dalam pendidikan informal harus selalu mengusahakan dan mengupayakan untuk memiliki sifat dan akhlak yang baik, salah satunya melalui belajar Al-Qur'an, memahami isi kandungannya dan

\footnotetext{
17 Jalaluddin, Filsafat pendidikan Islam: konsep dan perkembangan pemikirannya (Jakarta: Raja Grafindo Persada, 1994), 93.
} 
mengimplementasikan maknanya dalam kehidupan sehari-hari. Orang tua yang memiliki akhlak yang baik akan menghasilkan anak didik yang baik pula.

Kedua, adil. Adil sering dikatakan sebagai sikap yang moderat, objektif dalam menunaikan hak dan kewajiban, menempatkan sesuatu pada tempatnya, tidak harus sama rata, tetapi sesuai dengan porsinya. Orang tua sebagai pendidik harus memiliki sikap yang adil, dengan begitu ia akan melakukan sesuatu yang patut dan tidak sewenang-wenang.

Setiap anak lahir dengan potensi yang luar biasa, mereka istimewa dengan keunikan masing-masing, maka setiap individu layak dan perlu dihargai. Dengan sifat yang adil, seorang pendidik akan mampu bertindak sesuai dengan fitrah masingmasing anak, tidak membedakan antara yang satu dan yang lainnya. Selain itu, pendidik juga mampu mengembangkan potensi bawaan secara seimbang. Munif Chatib menyebutkan setiap anak memiliki kecenderungan kecerdasan berbeda dari sembilan kecerdaan yang ada, dan tugas orang tua adalah mengembangkannya. ${ }^{18}$

Begitu pentingnya sikap adil agar dimiliki oleh pendidik, Ibnu Sahnun menyebutkan dalam kitabnya bahwa saat seorang pendidik menangani tiga macam peserta didik namun tidak dapat berlaku adil terhadap mereka, maka pada hari kiamat akan dimasukkan ke dalam golongan orang-orang yang berkhianat. Terlebih bagi seorang pendidik yang menerima gaji dari profesinya dan ia tidak dapat berlaku adil, maka ia termasuk golongan orang-orang yang dhalim. ${ }^{19}$

Setiap interaksi yang dilakukan orang tua dengan anak akan melekat begitu kuat dalam ingatannya, itulah sebabnya dikatakan bahwa pola asuh yang baik akan membentuk karakter yang baik pada anak, karena anak merupakan peniru ulung. Perkembangan pesat otaknya di usia dini menjadikan ingatan mereka begitu melekat, karenanya keluarga harus selalu menjaga adab dan tingkah laku. Anak yang sejak dini dibekali dengan nilai-nilai yang baik dalam keluarga, ia akan tumbuh menjadi pribadi yang tangguh.

Ketiga, lemah lembut. Anak-anak memiliki jiwa yang lembut, maka untuk berinteraksi dengan mereka membutuhkan kelembutan. Setiap hal yang keluar dari hati dan disampaikan dengan hati maka akan mudah diterima dengan hati. Begitu juga ketika mengajar, sifat lemah lembut dan penuh kasih sayang sangat diperlukan

\footnotetext{
${ }^{18}$ Munif Chatib, Sekolahnya Manusia: Sekolah Berbasis Multiple Intelligences Di Indonesia (Bandung: Kaifa, 2015), 35.

${ }^{19}$ Sahnun, Adab al-Mu'allimin, 353.
} 
oleh orang tua. Sifat ini juga berkaitan dengan sifat sabar dan perhatian, seseorang yang bertindak dengan lemah lembut akan sabar dalam menghadapi seseorang.

Al-Qabisi mengungkapkan dalam kitabnya bahwasanya pendidik tidak boleh memukul peserta didik disebabkan oleh kelalaian atau kebodohan peserta didik, dan pukulan adalah upaya terakhir setelah teguran dan peringatan tidak mampu mengubah sikap peserta didik. Selain itu, pendidik dilarang memukul muridnya dikarenakan mereka tidak mampu memahami pelajaran atau karena kelemahan berpikirnya. $^{20}$

Setiap anak itu unik, ada yang mahir di bidang matematika tetapi dia lemah di bidang olahraga, ada juga yang mahir di bidang bercerita tapi lemah di bidang sosial. Anak yang punya kelemahan di satu sisi tidak bisa dikatakan anak tersebut bodoh, ia hanya pintar atau cerdas di bidang yang lain. Oleh karena itu, orang tua sebagai pendidik utama harus memiliki perangai yang lemah lembut dan sabar dalam menghadapi anak didiknya.

Keempat, berwibawa. Menurut KBBI wibawa adalah suatu sifat yang memperlihatkan kemampuan untuk mempengaruhi orang lain melalui tingkah laku yang mengandung kepemimpinan dan daya tarik. ${ }^{21}$ Sama halnya seperti sifat lainnya, wibawa seseorang perlu dibentuk melalui sebuah usaha. Namun yang perlu digarisbawahi adalah sifat wibawa tidak identik dengan pembawaan yang membuat orang lain takut atau segan secara berlebihan.

Ibnu Sahnun menjelaskan bahwa kewibawaan seseorang tidak tergantung pada fisik atau pakaian. Hal ini bukan bermaksud menafikan keindahan fisik atau kerapian pakaian, namun dikhawatirkan jika terlalu memperhatian fisik akan membuat hakikat wibawa yang sesungguhnya justru terabaikan. Menurut Ibnu Sahnun, seorang pendidik yang baju dan bibirnya terkena noda (tinta) maka itu adalah termasuk muru'ah (kehormatan). ${ }^{22}$

Noda dan tinta yang dimaksud di atas tidak hanya dimaknai secara tekstual tapi bisa secara kontekstual yaitu media dan metode pembelajaran. Dengan menghadirkan rasa antusias yang tinggi dalam mendidik anak, baik itu melalui strategi mengajar yang beragam atau alat-alat pembelajaran yang mendukung,

\footnotetext{
${ }^{20}$ Abu Hasan Ali Al-Qabisi, Ar-risalah al-Mufasshilah Li Ahwal al-Mu'allimin wa Ahkam al-Mu'allimin wa al-Muta'allimin (Kairo: Darul Ma'arif, 1968), 143.

21 "Hasil Pencarian - KBBI Daring," diakses 16 April 2020, https://kbbi.kemdikbud.go.id/entri/wibawa.

${ }^{22}$ Sahnun, Adab al-Mu'allimin, 354.
} 
niscaya akan menumbuhkan jembatan hati antara orang tua dan anak, antara pendidik dan peserta didik sehingga kewibawaan akan terbentuk dengan sendirinya.

Kelima, tanggung jawab. Sejatinya tugas mendidik adalah tanggung jawab mutlak sebagai orang tua, kemudian jika orang tua tidak mampu mendidik anaknya karena keterbatasan berbagai hal maka orang tua bertanggung jawab mencarikan guru untuk anaknya. Tanggung jawab mendidik dalam hal ini tidak hanya berkaitan dengan akademik melainkan juga dengan moral dan akhlak, maka seyogyanya semua orang tua mampu menjalin kerjasama yang solid dengan pihak sekolah dalam hal pendidikan seorang anak, tidak serta merta menyerahkan tanggung jawab pendidikan anak kepada pihak sekolah.

Ibnu Sahnun sangat menekankan tanggung jawab seorang pendidik terhadap peserta didik atau antara orang tua dengan anaknya. Beliau mengatakan bahwa tugas mendidik tidak dapat ditinggalkan meski dalam konteks ada agenda yang hukumnya fardhu kifayah sehingga mengharuskan untuk meninggalkan kegiatan mengajar, karena urusan mentarbiyah anak menempati urutan pertama dalam hubungan orang tua dan anak. Sedangkan urusan lain termasuk fardhu. Selain sebagai generasi penerus bangsa, anak juga merupakan amanat Allah. Amanat merupakan sesuatu yang akan dimintai pertanggungjawaban kepada seseorang yang diberikan amanat tersebut, karenanya orang tua harus benar-benar memahami tata cara mendidik anak sesuai aturan yang telah digariskan agar kelak mereka dapat mempertanggungjawabkan amanat yang telah diberikan kepadanya.

\section{Konsep Reward and Punishment}

Sebagai insan pembelajar tentunya akan banyak kekurangan yang dilakukan oleh seorang anak, maka dalam pendidikan ada metode yang dikenal dengan pemberian hukuman yang bertujuan untuk menciptakan dan menertibkan kedisiplinan. Namun yang perlu diketahui orang tua adalah setiap ragam pola asuh yang diterapkan akan memiliki potensi untuk menghasilkan berbagai ragam karakter anak. Oleh karena itu, ada aturan yang harus diketahui oleh orang tua atau pendidik dalam memberikan hukuman kepada seorang anak atau peserta didik.

Hukuman atau punishment berarti siksa atau perlakuan yang tidak menyenangkan bagi penerima. Di mana perlakuan tersebut adalah sebuah konsekuensi atas perbuatan buruk. Sedangkan menurut Ramayulis hukuman adalah perbuatan secara sadar atau disengaja oleh pemberi hukuman yang menyebabkan penderitaan kepada orang yang diberi hukuman, sebagai akibat dari kesalahan yang 
telah diperbuatnya. ${ }^{23}$ Tujuan dari hukuman sendiri adalah menciptakan suasana pembelajaran yang aman dan teratur sehingga anak didik dapat menjalankan tugasnya dengan baik.

Dalam berbagai media diberitakan macam-macam kekerasan yang dilakukan pendidik kepada peserta didik. Bahkan oleh orang tua kepada anaknya, sehingga tidak lama dari kejadian tersebut muncul sebuah larangan untuk menghukum anak secara fisik. Selang beberapa waktu kemudian, berbagai media memuat berita tentang kekerasan pada pendidik, namun pelakunya adalah peserta didik. Banyak para ahli yang menyoroti hal tersebut dan mengeluarkan pernyataan beragam, baik itu disebabkan oleh merosotnya moral anak bangsa, ada juga yang disebabkan oleh trauma psikologis seorang anak akibat penerapan hukuman yang salah.

Sebagian besar para ulama bidang pendidikan mulai dari Al-Ghazali, Ibnu Khaldun, dan Al-Qabisi sangat menentang punishment sebagai alat untuk mendidik, kecuali jika dalam keadaan terpaksa. Begitu juga dengan Ibnu Sahnun, beliau menyatakan bahwa pelaksanaan punishment harus dibatasi dan disesuaikan dengan jenis dan tingkat pelanggaran atau kesalahan anak. Dalam hal ini Ibnu Sahnun sangat memperhatikan psikologi anak, karena punishment membawa dampak terhadap perkembangan jiwa seorang anak. Beliau menegaskan bahwa pemberian punishment harus disertai niat untuk mendidik, bukan atas dasar kemarahan. ${ }^{24}$

Adapun syarat pemberian hukuman secara lebih rinci dipaparkan oleh Ibnu Sahnun sebagai berikut: a) hukuman hendaknya diberikan dengan kasih sayang, b) hukuman diberikan demi kemaslahatan anak, c) tidak menghukum anak semata-mata karena marah, d) tidak memukul anak lebih dari tiga kali, e) tidak memukul dengan alat yang membahayakan, f) tidak memukul area kepala dan wajah, g) tidak menyakiti anggota fisik yang lain secara berlebihan. ${ }^{25}$

Hukuman atau punishment merupakan sebuah metode pendidikan untuk membuat anak disiplin dan teratur, sehingga pada pola asuh ini orang tua dituntut untuk benar-benar mampu memahami keadaan anak. Berdasarkan konsep hukuman yang telah dipaparkan oleh Ibnu Sahnun di atas dapat disimpulkan bahwa orang tua harus mendahulukan metode pemberian reward dari pada punishment. Misalnya memberikan aturan kepada anak jika mereka tekun maka akan mendapat hadiah buku

\footnotetext{
${ }^{23}$ Ramayulis, Ilmu pendidikan Islam (Jakarta: Kalam Mulia, 2002), 302.

${ }^{24}$ Sahnun, Adab al-Mu'allimin, 355.

${ }^{25}$ Muhammad Arusi Mathwi, Muqoddimah Adab Al-Muallimin IbnSahnun (Tunis: Al-Manar, 1972), 90.
} 
cerita, bukan mendahulukan aturan jika mereka malas maka akan mendapatkan hukuman.

Apabila terpaksa memberikan hukuman pada anak, maka ada beberapa tahapan yang perlu dilakukan oleh orang tua. Pertama, apabila anak melakukan kesalahan yang wajar, orang tua hendaknya memberikan kesempatan untuk memperbaiki diri. Kedua, jika tahap pertama anak tidak mampu menyadari kesalahannya, maka orang tua boleh memberikan teguran atau kritikan. Ketiga, orang tua boleh memukul sesuai dengan adab yang telah dijelaskan. Para ulama juga sepakat bahwa memukul anak boleh dilakukan dengan tujuan untuk mendidik dan tidak dilakukan secara berlebihan.

Orang tua dituntut untuk memahami karakter anak dan selalu waspada dalam berinteraksi kepada anak, setiap hukuman yang diberikan oleh orang tua dapat memiliki dampak yang negatif, contoh: anak akan membenci orang tua dan berpikir untuk melakukan hal yang sama kepada orang tua atau bahkan guru dan temannya di sekolah. Selain itu, anak juga akan pandai menyembunyikan pelanggaran atau kesalahannya semata-mata karena takut dihukum. Akibat yang paling parah adalah anak kehilangan respek karena rasa takut berlebihan kepada orang tua.

4. Adab orang tua kepada pendidik

Tugas utama orang tua adalah mendidik anak-anaknya, baik itu dari segi intelektual, emosional, maupun spiritual, dalam materi akidah, syariah, dan akhlak. Ketika orang tua merasa tidak mampu untuk mendidik anaknya disebabkan oleh faktor rendahnya tingkat pengetahuan dan pendidikan, atau disebabkan oleh kesibukan orang tua dalam pekerjaan, maka orang tua wajib mencari dan memberi upah guru untuk mendidik anak-anaknya.

Oleh karena itu, keberhasilan pendidikan tidak serta merta tanggung jawab guru atau pihak sekolah, justru orang tua adalah orang pertama yang bertanggung jawab akan pendidikan anak-anaknya. Meski orang tua telah menyewa seorang guru, namun pengawasan dan pendampingan kepada anak harus tetap berjalan karena kewajiban mendidik anak tidak serta merta gugur, hanya saja berkurang. Demikianlah apabila setiap orang tua sadar akan setiap perannya dalam pendidikan, tentu tujuan pendidikan akan mudah dicapai.

Beberapa syarat yang harus dijadikan pertimbangan oleh orang tua dalam memilih guru untuk anaknya adalah ilmu dan akhlak yang dimiliki pendidik, karena seorang pendidik bisa menjadi figure tauladan bagi anak didik, terutama untuk anak- 
anak di tingkat sekolah dasar, mereka cenderung meniru apa yang dilakukan oleh guru mereka. Tidak sedikit kasus anak yang lebih mengikuti gurunya daripada orang tuanya, karenanya mutlak bagi orang tua untuk mempertimbangkan akhlak untuk memilih pendidik.

Menurut Ibnu Sahnun, orang tua wajib memberikan upah atas kinerja pendidik, namun seorang pendidik tidak dianjurkan untuk meminta lebih dari apa yang diberikan oleh orang tua, misalnya tunjangan atau hadiah khusus di luar upah yang diberikan oleh orang tua. ${ }^{26}$ Selain upah, orang tua juga dituntut untuk memperhatikan anak-anaknya, tidak serta merta menyerahkan tanggungjawab kepada gurunya karena meskipun sudah ada guru namun tanggung jawab orang tua tidak serta merta hilang.

Dari setiap paparan tersebut dapat diketahui betapa Ibnu Sahnun sangat detail dalam mengatur sistem pendidikan informal abad $2 \mathrm{H}$, sehingga tidak mengherankan apabila pendidikan anak-anak zaman dahulu terjamin kualitasnya baik di Kuttab maupun di rumah.

\section{Penutup}

Pendidikan informal memiliki peranan yang sama penting dengan pendidikan formal dan pendidikan nonformal, karenanya ketiganya harus saling melengkapi dan saling mengisi. Pendidikan informal dilakukan secara mandiri dalam lingkungan keluarga dengan tetap mengacu pada aturan-aturan tertentu, salah satunya adalah mengembangkan potensi anak baik itu intelektual, emosional, maupun spiritual.

Menurut Ibnu Sahnun kurikulum utama yang perlu diajarkan dalam pendidikan informal adalah Al-Qur'an. Selain memperkaya aspek spiritual anak, Al-Qur'an juga dapat memperkaya aspek intelektual dan emosional. Orang tua sebagai pendidik utama dalam pendidikan informal harus membekali dirinya dengan ilmu pengetahuan dan membentuk kepribadian mulia dalam dirinya, seperti sifat taqwa, ikhlas, sabar, lemah lembut, dan tidak semena-mena dalam memberi hukuman. Semua itu dimaksudkan agar dapat menjadi tauladan bagi anak-anaknya, karena orang tua adalah pemegang kewajiban mutlak dalam hal mendidik anak. Oleh karena itu, ketika orang tua tidak mampu mendidik anaknya, maka ia wajib mencarikan guru dengan pertimbangan ilmu

\footnotetext{
${ }^{26}$ Sahnun, Adab al-Mu'allimin, 358.
} 
dan akhlak. Namun tetap saja orang tua harus terus mengawasi setiap perkembangan anaknya.

\section{Daftar Rujukan}

Al-Qabisi, Abu Hasan Ali. Ar-risalah al-Mufasshilah Li Ahwal al-Mu'allimin wa Ahkam al-Mu'allimin wa al-Muta'allimin. Kairo: Darul Ma'arif, 1968.

Arifin, Yanuar. Pemikiran-Pemikiran Emas Para Tokoh Pendidikan Islam. IRCiSoD, 2018.

Arikunto, Suharsimi. Prosedur penelitian: suatu pendekatan praktik. Jakarta: Rineka Cipta, 2011.

Chatib, Munif. Orangtuanya Manusia: Melejitkan Potensi dan Kecerdasan dengan Menghargai Fitrah Setiap Anak. Bandung: Kaifa, 2013.

—. Sekolahnya Manusia: Sekolah Berbasis Multiple Intelligences Di Indonesia. Bandung: Kaifa, 2015.

Hakim, Nur. "Kecerdasan Intelektual, Emosional, Dan Spiritual Dalam Perspektif Bidayatul Hidayah.” Indonesian Journal of Islamic Education Studies (IJIES) 1, no. 2 (27 Desember 2018): 218-33. https://doi.org/10.33367/ijies.v1 i2.639.

Hamalik, Oemar. Kurikulum dan pembelajaran. Jakarta: Bumi Aksara, 2017.

Hanindita, Meta. Mommyclopedia. Jakarta: Gramedia, 2019.

"Hasil Pencarian - KBBI Daring.” Diakses 16 April 2020. https://kbbi.kemdikbud.go.id/entri/wibawa.

Hatimah, Ihat. "REGULASI DAN IMPLEMENTASI PENDIDIKAN INFORMAL." $\begin{array}{lllll}\text { PEDAGOGIA } & 13, & \text { no. } & 1 & \text { (2015): }\end{array}$ https://doi.org/10.17509/pedagogia.v13i1.3387.

Jalaluddin. Filsafat pendidikan Islam: konsep dan perkembangan pemikirannya. Jakarta: Raja Grafindo Persada, 1994.

Mardalis. Metode penelitian: suatu pendekatan proposal. Jakarta: Bumi Aksara, 2014.

Mas'ud, Abdurrahman. Pemikiran Emas Para Tokoh Pendidikan Islam. Yogyakarta: Arruz Media, 2017.

Mathwi, Muhammad Arusi. Muqoddimah Adab Al-Muallimin IbnSahnun. Tunis: AlManar, 1972.

Nazir, Moh. Metode penelitian. Jakarta: Ghalia Indonesia, 2011.

Ramayulis. Ilmu pendidikan Islam. Jakarta: Kalam Mulia, 2002.

Sahnun, Muhammad bin. Kitab Adab al-Muallimin, pentahqiq Hasan Husni Abdul Wahhab, cet baru; murajaah dan komentar oleh Muhammad Arusi Al-Mathwi. Tunis: Dar Bussalamah Li Thab'ah wan Nasyr, t.t.

Sahnun, Muhammad Ibn. Adab al-Mu'allimin. Kairo: Darul Ma'arif, 1968.

Sahrizal, dan Rabi'atul Adawiah. Pemikiran Pendidikan Islam Ibnu Sahnun. Miqot, 2012.

“Undang-Undang Nomo2 30 tahun 2003 tentang Sistem Pendidikan Nasional,” 2003. 